\title{
Breaking Seed Dormancy: Revisiting Heat-treatment Duration on Germination and Subsequent Seedling Growth of Oil Palm (EIaeis guineensis Jacq.) Progenies
}

\author{
Nicolas Y. Fondom (Corresponding author) \\ Department of Plant and Animal Science, University of Buea, Cameroon \\ E-mail: fondomn@yahoo.fr \\ Culbertson E. Etta \\ Pamol Research Unit, Lobe Estate, Cameroon \\ Afui M. Mih \\ Department of Plant and Animal Science, University of Buea, Cameroon
}

\begin{abstract}
The role of duration of various varying heat-treatment durations on the germination of oil palm seeds is well documented. We investigated the effects of different heat-treatment durations on germination and seedling growth of 10 oil palm progenies. Batches of 250 oil palm seeds from each progeny were heat-treated at a temperature of $39^{\circ} \mathrm{C} \pm 1^{\circ} \mathrm{C}$ for $60,80,100$ and 120 days, to break dormancy. Seedling growth parameters measured included rate of leaf production, leaf area and relative leaf area growth rate, rate of leaf elongation, and diameter of base of seedlings stem. Germination rates for $60,80,100$, and 120 days combined were highest for progenies A5240 and A5221 (> $80 \%$ ) but very low (< 5\%) for progenies A5228 and A5268. Progenies A5240, A5291, A5234 and A5221 were found to be the most outstanding progenies in terms of germination. Prolonged heat-treatment resulted in reduced germination and less vigorous seedling growth. Heat-treatment of 60 days gave the best seedling growth performance and seedling growth was adversely affected when heat-treatment exceeded 100 days. The study indicated that heat-treatment duration of 60 days and not 80 days was effective for breaking dormancy of the oil palm seeds and successful seedling growth. This study shows that oil palm seeds germination can be obtained successfully within a short period (60 days) of heat-treatment compared to the current 80 days application by PAMOL Plantation Ltd. Lobe estate. These results could provide significant solutions to the numerous demands of oil palm seeds by local farmers.
\end{abstract}

Keywords: Oil palm (EIaeis guineensis Jacq.), Progeny, Dormancy, Germination, Leaf area, Relative leaf area growth rate

\section{Introduction}

The oil palm, EIaeis guineensis Jacq., is an important source of vegetable oil cultivated in plantations and small farms in Southeast Asia and also Western Africa (Hartley 1988; Opeke 1992). However, fossil and historical evidence, including personal communications suggest that the oil palm originated in the tropical rainforest of West Africa (Hartley 1988; Tan 1983; Purseglove 1972). The oil palm produces oil from the fruit mesocarp (crude palm oil) and palm kernel oil from the seed (Hartley 1988). In commercial seed production, vegetative parental parameters are studied for a period of not less than eight years before selection for a parent plant is made (Wonkyi-Appiah 1999). These parameters includes stem elongation, high fruit weight to fruit bunch ratio, high oil to bunch ratio, reasonable kernel size to bunch ratio, early fruiting, thin endocarp and a thick mesocarp, and tolerance to Fusarium wilt (Fusarium oxysporum F. sp. Elaeidis). The commercial oil palm tenera hybrids are a cross between the dura type (thin mesocarp, thick endocarp, with generally large kernel) and the pisifera type (thick mesocarp, no endocarp with small or no kernel). The hybrid tenera type has a thin endocarp (0.5 to 3 $\mathrm{mm}$ thick), a medium to high mesocarp, and reasonable kernel size. The improved oil palm progenies ensuing from the hybrid tenera type go into production 3 to 4 years after field plantings. However, the timing and productivity of the hybrid tenera type depends greatly on how well the plantation is managed (Onwueme and Sinha 1991). 
Like most seeds with very thick seed-coat (testa), the oil palm seeds pose difficulties in seed germination because of a long dormancy ( 1 to 2 years) after it is harvested (Mok 1982; Herrera et al. 1999) which is attributed to restrictions of embryo growth due to mechanical constraints and the oxygen uptake by the compact "stony" endospermous tissue of the oil palm seeds (Mok 1982; Hussey 1958). As a result, a period of increased temperature with sufficient seed moisture is required for rapid and maximal oil palm seed germination (Mok 1982; Rees 1962). Naturally, oil palm seeds are pre-treated with heat resulting from the exothermic decomposition of the oily mesocarp by fungi and other microorganisms (Alang et al. 1988). However, this natural process is very slow and few seeds germinate. On the other hand, in controlled heat-treatment, the seeds for germination are stored at a temperature range of 38 to $40^{\circ} \mathrm{C}$ for 90 days at $18 \%$ moisture content (Rees 1962). Germination of the oil palm seed by heat-treatment has been described by Hussey (1958), Rees (1962), Corley (1982), Mok (1982), and Periasamrny et al. (2002). On the other hand, none of these studies investigated the physiological effects of various duration of heat-treatment on subsequent seedling growth. Currently, the research laboratory at PAMOL Plantation Ltd, Cameroon, which commercially produces germinated oil palm seeds, incubates seeds at $39 \pm 1^{\circ} \mathrm{C}$ for 80 days, and this generally gives a low germination rate $(<50 \%)$. As a result, large quantity of seeds is wasted resulting in difficulties for meeting the plantation's demand for germinated seeds. It is therefore necessary to investigate how different durations of heat-treatment could improve inconsistencies in supply of germinated seeds. The objectives of this study were to investigate the effects of different heat-treatment durations on the germination of some PAMOL commercial tenera oil palm progenies and the effects of different heat-treatment durations upon seedling growth.

\section{Materials and Methods}

\subsection{Location of the study}

This study was conducted in the seed production unit and demonstration nursery at the research laboratory of PAMOL Plantation Ltd in Ekondo Titi Sub-Division $\left(04^{\circ} 34\right.$ to $04^{\circ} 40 \mathrm{~N}$ and $09^{\circ} 04$ to $\left.09^{\circ} 10 \mathrm{E}\right)$, the South West of Cameroon. The location's benefits from the equatorial climate, which is characterized with an annual rainfall of $3,559 \mathrm{~mm}$, relative humidity of $90 \%$ and an annual temperature of $27^{\circ} \mathrm{C}$. The year is divided into two seasons: dry season that runs from December to February, but interrupted with light rain, and a rainy season, which runs from March to November each year. These periods of two rainy seasons are the result of the Intertropical Convergence Zone (ITCZ), which influences the climate of this equatorial area. The soil is sandy clay and chemically poor (low organic content), but generally appreciable for oil palm cultivation (Awah et al. 1984). Oil palm seeds used for this study were obtained from controlled pollinations intended for commercial tenera seed production by the research unit (Table 1). The fresh fruit bunches for seed production, were harvested at 1 to 10 loose fruits stage of ripeness (Tiong et al. 1994). To extract the seeds, the fruits were retted and de-pericarped mechanically.

\subsection{Pre-treatment measurements (Seed size and viability)}

Samples of 20 oil palm seeds from each of the 10 progenies (Table 1) were used for seed size determination. The length and breadth of each seed were measured with a digital caliper (Mitutoyo, Aurora, IL) and the seed size $(\mathrm{cm})$ was the mean of length and breadth. Seed viability was tested on 50 sampled seeds from each progeny by tetrazolium chloride viability test. The endocarp of each seed was removed to obtain the endosperm. The embryo of each endosperm was in placed in 1\% (10 gm/l) aqueous solution of tetrazolium chloride and kept under dark condition for 6 to 8 hours. A change in embryo coloration to partially or completely red or pink indicated viable seeds. Progenies with viability greater than or equal to $86 \%$ were selected for germination.

\subsection{Application of heat-treatment duration}

Random sample of 250 seeds of each progeny selected from three months stored seeds were sprayed with a mist sprayer of distilled-water to raise the moisture content required for germination (approx. $18 \%$ ). Seed moisture content was measured with a hygrometer (Rotronic Instrument Corp., Hauppauge, NY). The moist seeds were kept in two $40 \mathrm{~cm}$ by $40 \mathrm{~cm}$ polythene bags for heat-treatment at $60,80,100,120$ days durations at temperature of $39 \pm 1^{\circ} \mathrm{C}$ in a germinator. After heat-treatment, the 250 seeds of each progeny were removed from the germinator and brought to the required moisture content for germination by soaking in distilled-water for 7 days. The water was changed daily to avoid microbial contamination. The seeds were then stored in a $40 \mathrm{~cm}$ by $40 \mathrm{~cm}$ polythene bag and assessed for germination after 14 days of storage for first sorting and 7 days later for the second sorting. Percentage germination was estimated as follows:

$$
\% \text { Germination }=\frac{\text { Number of germinated seeds }}{\text { Number of seed incubated }(250 \text { seeds })} * 100
$$




\subsection{Nursery establishment and management}

Polythene bags of size $40 \mathrm{~cm}$ by $35 \mathrm{~cm}$ were filled with free-draining sandy clay soil. Progenies A5240, A5291, A5234, and A5221, with $50 \%$ or more germination rate (Table 3) were tested on a Randomized Complete Block design with three replicates. In a split plot design, heat-treatment durations of 60, 80, 100, and 120 days were main plots and progenies as sub plots (36 polythene bags per sub-plots). Each sub-plot was separated from each other by a path of $100 \mathrm{~cm}$ wide. The germinated seeds from the heat-treatment were planted $1 \mathrm{~cm}$ deep ensuring that the plumule (shoot) was placed upward and the radicle (root) downwards in an open top nursery. For each sub-plot, 20 border seedlings acted as guard plants to take care of edge effects while the remaining 16 internal seedlings were used for data sampling.

Drip-irrigation technique was applied when needed and weeds were carefully removed by hand ensuring that the tender roots of the seedlings were neither disturbed nor damaged. A small quantity $(0.0025 \%$ per seedling) of Carboforan (FMC Corporation, Philadelphia, PA), and 4g/L Mancozeb (DuPont Agricultural Products, Wilmington, DE) were used for insects and fungi control. Liquid fertilizer mixture was applied weekly at a rate of $40 \mathrm{ml}$ per seedling. The composition of liquid fertilizer is $14.00 \mathrm{~g}$ sulphate of ammonia (2.94 g nitrogen), $14.00 \mathrm{~g}$ kieserite (2.27 $\mathrm{g}$ magnesium), and $28.00 \mathrm{~g}$ muriate of potash (13.94 g potassium) in 10, $000 \mathrm{ml}$ of water.

\subsection{Vegetative growth measurements}

Measurements and calculations on vegetative traits on the nursery oil palm seedlings were conducted according to Corley and Breure (1981) with minor modifications on rate of leaf production, diameter of base of stem, plant growth increment, leaf area and relative leaf area growth rate $\left(\mathrm{R}_{\mathrm{A}}\right)$. The rate of leaf production per week was estimated based on number of leaves produced between 12 and 16 weeks of growth after planting. Diameter of base of stem at widest point was measured with a digital caliper (Mitutoyo, Aurora, IL) at right angles to the seedlings at 16 weeks of growth after planting. For plant growth increment, the height from soil surface to the tip of the youngest spear leaf of each seedling was measured at 12 and 16 weeks of growth after planting. Plant growth increment was estimated the height difference at 12 and 16 weeks of growth after planting.

Leaf area was measured with a portable LI-3300 area meter (LICOR, Inc., Lincoln, Nebraska). Total leaf area of a seedling was calculated as the sum of all leaf areas produced at the time of measurement. The first measurement for total leaf area $\left(A_{1}\right)$ was estimated at 12 weeks $\left(t_{1}\right)$ of growth after planting. The second measurement $\left(\mathrm{A}_{2}\right)$ was repeated at 16 weeks $\left(\mathrm{t}_{2}\right)$ of growth after planting. Relative leaf area $\left(\% \mathrm{R}_{\mathrm{A}}\left(\mathrm{cm}^{2} / \mathrm{cm}^{2}\right.\right.$ day $\left.^{-1}\right)$ were estimated as:

$$
\% \mathrm{R}_{\mathrm{A}}\left(\mathrm{cm}^{2} / \mathrm{cm}^{2} \mathrm{day}^{-1}\right)=\frac{\log _{\mathrm{e}} \mathrm{A}_{2}-\log _{\mathrm{e}} \mathrm{A}_{1}}{\mathrm{t}_{2}-\mathrm{t}_{1}} * 100
$$

\subsection{Data analysis}

Where appropriate, data from parameters measured were analyzed using two-way Analysis of Variance (ANOVA) using Sigmastat 3.1 (SYSTAT, San Jose, CA) software. Differences were considered statistically significant at $P<0.05$.

\section{Results}

\subsection{Pre-treatment measurements (Seed size and viability)}

Our results showed that seed size range from $1.45 \mathrm{~cm}$ to $2.38 \mathrm{~cm}$. Progeny A5224 had the smallest seed size while progeny A5234 had the highest seed size (Table 2). For tetrazolium chloride viability test of seed embryos, test showed that all ten progenies were physically and chemically viable (viability $>86 \%$ ). Though all ten progenies were potentially viable, six of the ten progenies had percentage viability greater than 90 whereas four progenies (A5200, A5228, A5281, and A5268) had less than $90 \%$ viable seeds. However, all ten progenies were selected for germination by heat-treatment.

\subsection{Germination rate}

The germination percentages of the ten oil palm progenies after heat-treatment for 60, 80, 100, and 120 days in the germinator are shown in Table 2. Our results indicated that under the same heat-treatment condition $\left(39 \pm 1^{\circ} \mathrm{C}\right.$ and approx. $18 \%$ moisture content), 60 days duration in the germinator produced the highest mean percentage germination $(66.22 \pm 9.58)$ followed by 80 days duration $(44.36 \pm 10.82)$. However, germination rates were lethal for 100 days and 120 day durations with mean germination rate of less than $30 \%$ (Table 2). Within the ten progenies, germination rates for 60, 80, 100, and 120 days combined were highest for progenies A5240 and A5221 ( $>80 \%$ ) but very low (<5\%) for progenies A5228 and A5268. However, all four progenies (A5200, 
A5228, A5281, and A5268) with seed viability less than $90 \%$ had a mean germination rate of less than $25 \%$ (Table 2).

Based on the percentage germination rate, four progenies (A5240, A5291, A5234, and A5221) in Table 3 were selected for further assessments of varying heat-treatment durations on seedling growth. Within these four progenies, the mean percentage germination rate was significantly higher for 60 days compared to 80,100 , and 120 days. However there was no significant difference in the mean percentage germination rate for both 100 and 120 days durations (Table 3 ). Within progenies, germination rates for $60,80,100$, and 120 days combined were significantly higher for progenies A5240 and A5221 compared to progenies A5291 and A5234 (Table 3).

\subsection{Vegetative growth measurements}

Seedling rate of leaf production for progenies A5240 and A5291 was not significantly different for 80, 100, and 120 days but was significantly higher for 60 days heat-treatment duration. For progeny A5234, no significant difference in the rate of leaf production was observed for 60,80 , and 100 days heat-treatment durations, however, 120 days heat-treatment duration significantly reduced the rate of leaf production. Finally, progeny A5221 also showed a significant reduction in the rate of leaf production with heat-treatment durations, however, there was no significant difference between 80 and 100 days heat-treatment durations. Overall, the rate of leaf production for progenies A5240, A5291, and A5221 was significantly higher for 60 days compared to 80, 100, and 120 days durations of heat-treatment (Fig. 1a).

Like rate of leaf production, the diameter of base of stem for progenies A5240 and A5291 was not significantly different for 80, 100, and 120 days heat-treatment durations but was significantly higher for 60 days heat-treatment duration. For progenies A5234 and A5221, our result showed no significant difference in the diameter of base of stem between 60 and 80 days heat-treatment durations, but was significantly different for 100 and 120 days heat-treatment durations. Overall, the seedling diameter of base of stem for all four progenies showed decreasing trend with heat-treatment durations (Fig. 1b)

Plant growth increment showed decreasing trend with heat-treatment durations (Fig. 3). For progeny A5240, plant growth increment was significantly higher for 60 days heat-treatment durations and also significantly different for all four heat-treatment durations. For progeny A5291, plant growth increment was significantly higher for 60 days compared to 80,100, and 120 days heat treatment durations. However, for this progeny (A5291) there was no significant difference in plant growth increment for 80,100, 120 days heat-treatment durations. Whereas for progeny A5234, plant growth increment was significantly lower for 120 days compared to 60,80 , and 100 days heat-treatment durations. However, this progeny (A5234) did not show any significant difference in plant growth increment for 60,80 and 100 days heat-treatment durations. Finally, for progeny A5221, plant growth increment was significantly higher for 60 and 80 days compared to 100 and 120 days (Fig. 2).

Seedling leaf area for progenies A5240 and A5221 was significantly higher for 60 and 80 days compared to 100 and 120 days heat-treatment durations. For progenies A5291 and A5234, leaf area significantly higher for 60 days and significantly lower for 120 days but was not significantly different for 80 and 100 days heat-treatment durations. Overall, seedling leaf area also showed a decreasing trend with heat-treatment durations (Fig. 3a).

Seedling relative leaf area growth rate like leaf area for progeny A5240 was significantly higher for 60 and 80 days compared to 100 and 120 days heat-treatment durations. For progenies A5291, A5234, and A5221, relative leaf area growth rate was significantly higher for 60 days compared to 80, 100, and 120 days heat-treatment durations. However, for these progenies, there was no significant difference in seedling relative leaf area growth rate between 80 and 120 days for progeny A5291, between 80 and 100 days for progeny A5234, and between 100 and 120 days for progeny A5221. Overall, seedling relative leaf area growth rate also showed a decreasing trend with heat-treatment durations (Fig. 3b).

\section{Discussion}

The present study has elucidated the potential of 60 days heat-treatment durations as optimal for germination of the oil palm seeds. In a recent study, Beugré et al. (2009) also reported significant success in oil palm seeds germination for 60 days compared to 40 and 80 days heat-treatment durations. On the other hand, Soh et al. (2009) suggested a 50 days heat-treatment at a temperature range of 37 to $39^{\circ} \mathrm{C}$ will provide an optimum germination for oil palm seeds. Our results and that of Beugré et al. (2009) contradict earlier reports by Hussey (1958) and Rees (1962) suggesting an optimum heat-treatment duration of 80 days at a temperature range of 38 to $40^{\circ} \mathrm{C}$. According to Hussey (1958) the optimum temperature range of 38 to $40^{\circ} \mathrm{C}$ accelerated the germination process of oil palm seeds in pure oxygen. Hussey (1958) postulated that the germination of oil palm seeds is 
dependent upon a minimal oxygen concentration within the embryo of the oil palm seed. Like in most seed plants, the complete absence of oxygen inhibits the process of seed germination.

Within each treatment, there were differences in percentage seed germination with the ten oil palm progenies tested (Table 2). These differences may be attributed to the genetic constitution of each oil palm progeny (Posenquist 1999). The decrease in germination with increasing heat treatment duration was consistent with the findings of Mok (1982) and Gashaw and Michelsen (2002). They (Mok 1982; Gashaw and Michelsen 2002) attributed the adverse effects of germination to prolonged heating of the oil palm seeds in the germinator. It should be noted that the endocarp of the oil palm seeds functions as a poor insulator, conducting small amount of heat to the endosperm during the heat treatment. Thus, prolonged heating will result in temperature increase in the endocarp, which may be transferred to the endosperms, causing reduction in enzyme activities, thus adverse effects to germination and seedling growth (Breure 1982).

The seedling growth responses reported here following varying durations of heat-treatment to break dormancy in the oil palm progenies may provide some clues as to how prolong heat-treatment durations would influence the patterns of development in post nursery establishment. Our results showed that all seedling growth parameters measure decreased with increasing heat-treatment durations. These results suggest that the successful growth of these oil palm seedlings were impaired by the prolong heat-treatment in the germinator. The heat-treatment germination of oil palm seeds for more that 80 days are especially not worthy given that under natural conditions, oil palm seed germination require successive short periods of heat-treatment. These successive short periods of heat-treatment usually occur during the dry season and in most cases, the germination rate is very slow (1 to 3 years) with very small percentage germination compared to commercial germination. However, field/natural germination is influenced by other factors, which include seed age, moisture content, the presence of pathogens, and seed predators.

\section{Conclusions}

In summary, increasing duration of heat-treatment to break dormancy in the commercial oil palm progenies negatively affected seed germination and also subsequent seedling growth. This study has shown that heat-treatment duration of 60 days and not 80 days was effective for breaking oil palm seed dormancy and successful seedling growth. With respect to seed germination, progenies A5240, A5291, A5234, and A5221 were the most outstanding progenies, out of the ten progenies tested. These four progenies can be used for the genetic selection program for commercial oil palm seed production. The study described here shows that oil palm seeds germination can be obtained within a short period (60 days) of heat-treatment compared to the current 80 days application by PAMOL Plantation Ltd. Lobe estate. This shorter duration of heat-treatment, which results in significant percentage germination could provide considerable solutions to the numerous demands of oil palm seeds by local farmers and also more profit to the plantation estate.

\section{Acknowledgements}

This work was supported by funds from the research unit of PAMOL Plantation Ltd Lobe Estate, Cameroon. We wish to thank the workers at the research laboratory of PAMOL Plantation Ltd for helping us with seed processing and nursery management. This article represents a portion of a MSc thesis submitted by N.Y. Fondom to the Department of Plant and Animal Science at University of Buea, Cameroon.

\section{References}

Alang, Z.C., Moir, G.F.J., and Jones, L.H. (1988). Composition, degradation and utilization of endosperm during germination in the oil palm (Elaeis guineensis). Annals of Botany 61, 261-268.

Awah, E.T., Hof, J., Nyore, T., and Tambe, P. (1984). Soil survey and land evaluation of Pamol, Lobe Estate. National Soils Center Ekona Station, FAOAJNDP Project.

Beugré, M.M., Kouakou, K. L., Bognonkpé, J.P., Konan, K.E., Kouakou, T.H., and Kouadio, Y.J. (2009). Effect of storage and heat treatments on the germination of oil palm (Elaeis guineensis Jacq.) seed. African Journal Agricultural Research 4, 931-937.

Breure, C.J. (1982). Factors affecting yield and growth of oil palm tenera in West New Britain. Oleagineux 37, 213-227.

Corley, R.H.V., and Breure, C.J. (1981). Measurements in Oil Palm Experiments. Internal Report, Unilever Plantation Group. London.

Corley, R.H.V. (1982). Germination and seedling growth. In Corley, R.H.V., J.J. Hardon, and B.J. Wood, (Eds), Developments in Crop Science I (pp. 23-36). Elsevier, Amsterdam. 
Gashaw, M. and Michelsen, A. (2002). Influence of heat shock and seed germination of plants from regularly burnt savanna woodlands and grasslands in Ethiopia. Plant Ecology, 159, 83-92.

Hartley, C.W.S. (1988). The Oil Palm. Longman Scientific and Technical publication, Wiley, New York.

Herrera, J., Aliiga, R., and Guevara, E. (1999). Induction of the Germination in Seeds of Oil Palm (Elaeis guineensis Jacq.) using chemical treatments. ASD, Costa Rica.

Hussey, G. (1958). An analysis of the factors controlling the germination of the seed of the oil palm, Elaeis guineensis (Jacq.). Annals of Botany 22, 259-284.

Mok, C.K. (1982). Heat requirement for breaking dormancy of the oil palm seeds after storage under different conditions. In Pushparajah, E. and P.S. Chew, (Eds.), The Oil Palm in Agricultural Development in the Eighties (pp. 197-206). The Incorporated Society of Planters, Kualar Lumpur.

Onwueme, I.C. and Sinha, T.D. (1991). Field Crop Production in Tropical Africa. CTA, Wageningen, Netherlands.

Opeke, L.K. (1992). Tropical Tree Crops. Spectrum Books Limited. Ibadan.

Periasamy, A., Gopapal, K and Soh, A.C. (2002). Productivity improvements in seed processing techniques for commercial oil palm seed production. The Planter, 78, 429-442.

Purseglove, J.W. (1972). Tropical Crops, Monocotyledons. Halsted Press Division, Wiley, New York.

Rees, A. R. (1962). High-temperature pre-treatment and germination of seed of oil palm, Elaeis guineensis (Jacq.). Annals of Botany, 26, 569-581.

Rosenquist, E.A. (1999). Some ancestral palms and their descendants. In Rajanaidu, N. and B.S. Jalani (Eds.), Proceedings of the Symposium on the Science of Oil Palm Breeding (pp. 8-36). PORIM. Kualar Lumpur.

Soh, A.C., Wong, C.K.Y., Ho, W., and Choong, C.W. (2009). Oil palm. In Vollmann, J. and I. Rajcan (Eds.), Handbook of plant breeding, (pp. 333-367). Springer New York.

Tan, K.S. (1983). The Botany of the Oil Palm. The Incorporated Society of Planters. Kualar Lumpur.

Tiong, G.L., Yee, H.C., Seng, C.J., Seng, L.K., and Tang, K.T. (1994). Recent development in harvesting practices to maximize labour, productivity, oil yields and profits. In Chee, K.H. (Ed.), Management for Enhanced Profitability in Plantations (pp. 315-332). International Planters Conference, Kuala Lumpur.

Wonkyi-Appiah, J.B. (1999). Oil palm breeding in Ghana. In Rajanaidu, N. and B.S. Jalani (Eds.), Proceedings of the Symposium on the Science of Oil PaIm Breeding (pp. 165-189). PORIM, Kualar Lumpur. 
Table 1. The parentage and origin of the oil palm (EIaeis guineensis Jacq.) progenies used for heat-treatment germination. Abbreviations includes; INEAC, Institut national pour l'étude agronomique du Congo; NDN, Ndian

\begin{tabular}{|c|c|c|c|c|c|}
\hline Progenies & $\begin{array}{l}\text { Parentage } \\
\text { Dura x Pisifera }\end{array}$ & $\begin{array}{l}\text { Grand Dura } \\
\text { Progeny } \\
\text { Code }\end{array}$ & $\begin{array}{l}\text { Grand Dura } \\
\text { Origin }\end{array}$ & $\begin{array}{l}\text { Grand } \\
\text { Pisifera } \\
\text { Progeny } \\
\text { Code } \\
\end{array}$ & $\begin{array}{l}\text { Grand } \\
\text { Pisifera } \\
\text { Origin }\end{array}$ \\
\hline A5207 & $\begin{array}{l}12 / 1918 x \\
12 / 2709\end{array}$ & Lb 130 & Ekona x Ekona & Lb 135 & $\begin{array}{l}\text { Angola x } \\
\text { Angola }\end{array}$ \\
\hline A5240 & $\begin{array}{l}13 / 1736 x \\
12 / 2709\end{array}$ & Lb 240 & Ekona $\mathrm{x}$ INEAC & Lb 135 & $\begin{array}{l}\text { Angola x } \\
\text { Angola }\end{array}$ \\
\hline A5291 & $\begin{array}{l}13 / 1640 \mathrm{x} \\
12 / 12433\end{array}$ & Lb 235 & $\begin{array}{l}\text { Deli (NDN) x } \\
\text { INEAC }\end{array}$ & Lb 158 & $\begin{array}{l}\text { Ekona x } \\
\text { Ekona }\end{array}$ \\
\hline A5234 & $\begin{array}{l}13 / 1066 \mathrm{x} \\
12 / 2709\end{array}$ & $\mathrm{Lb} 240$ & Ekona x INEAC & Lb 135 & $\begin{array}{l}\text { Angola x } \\
\text { Angola }\end{array}$ \\
\hline A5200 & $\begin{array}{l}13 / 0251 \times \\
12 / 12428\end{array}$ & Lb 235 & $\begin{array}{l}\text { Deli (NDN) x } \\
\text { INEAC }\end{array}$ & Lb 158 & $\begin{array}{l}\text { Ekona } \mathrm{x} \\
\text { Ekona }\end{array}$ \\
\hline A5228 & $\begin{array}{l}13 / 3249 x \\
12 / 12433\end{array}$ & $\mathrm{Lb} 275$ & Ekona x Ekona & Lb 158 & $\begin{array}{l}\text { Ekona x } \\
\text { Ekona }\end{array}$ \\
\hline A5281 & $\begin{array}{l}13 / 2937 \mathrm{x} \\
12 / 12433\end{array}$ & Lb 258 & Ekona x Ekona & Lb 158 & $\begin{array}{l}\text { Ekona } \mathrm{x} \\
\text { Ekona }\end{array}$ \\
\hline A5221 & $\begin{array}{l}13 / 1154 \mathrm{x} \\
12 / 12433\end{array}$ & $\mathrm{Lb} 230$ & $\begin{array}{l}\text { Deli x (Deli x } \\
\text { Ekona) }\end{array}$ & Lb 158 & $\begin{array}{l}\text { Ekona } \mathrm{x} \\
\text { Ekona }\end{array}$ \\
\hline A5268 & $\begin{array}{l}13 / 3249 x \\
12 / 12433\end{array}$ & Lb 257 & Ekona x Ekona & Lb 158 & $\begin{array}{l}\text { Ekona x } \\
\text { Ekona }\end{array}$ \\
\hline A5224 & $\begin{array}{l}12 / 7978 x \\
12 / 12433 \\
\end{array}$ & $\mathrm{Lb} 8$ & $\begin{array}{l}\text { Aba x (Angola X } \\
\text { Deli) }\end{array}$ & Lb 158 & $\begin{array}{l}\text { Ekona } \mathrm{x} \\
\text { Ekona }\end{array}$ \\
\hline
\end{tabular}

Table 2. Percentage germination rate of ten oil palm progenies exposed to different durations of heat-treatment to break dormancy. Values are cumulative number of seeds germinated after second sorting as a percentage of seeds incubated

\begin{tabular}{llllllll}
\hline & \multicolumn{7}{c}{ Heat-Treatment Duration } \\
\cline { 2 - 7 } Progenies & Seed Size & $\mathbf{6 0}$ days & $\mathbf{8 0}$ days & $\mathbf{1 0 0}$ days & $\mathbf{1 2 0}$ days & Means & SE \pm \\
\hline A5207 & 1.49 & 59.61 & 40.41 & 00.00 & 00.00 & 25.01 & 14.96 \\
A5240* & 1.70 & 92.43 & 86.89 & 81.61 & 82.84 & 85.94 & 2.44 \\
A5291* & 2.38 & 84.00 & 68.85 & 41.29 & 30.81 & 56.24 & 12.25 \\
A5234* & 1.81 & 85.21 & 75.20 & 10.01 & 30.03 & 50.11 & 17.96 \\
A5200 & 1.54 & 64.47 & 08.87 & 14.17 & 00.80 & 22.08 & 14.40 \\
A5228 & 1.46 & 15.63 & 02.04 & 00.00 & 02.02 & 04.92 & 3.60 \\
A5281 & 1.52 & 52.00 & 21.23 & 06.09 & 04.09 & 20.85 & 11.07 \\
A5221* & 1.81 & 94.81 & 85.21 & 90.00 & 68.12 & 84.54 & 5.81 \\
A5268 & 1.49 & 17.64 & 01.63 & 00.00 & 00.83 & 05.03 & 4.22 \\
A5224 & 1.45 & 96.42 & 53.24 & 32.82 & 05.63 & 47.03 & 19.14 \\
Means & & 66.22 & 44.36 & 27.60 & 22.52 & & \\
SE \pm & & 9.58 & 10.82 & 10.68 & 9.62 & & \\
\hline
\end{tabular}

The symbol $*$ indicates progenies with optimal mean germination $\geq 50.00 \%$. These progenies were selected for nursery establishment. 
Table 3. Percentage germination rates of selected progenies for nursery establishment with mean germination rate of $50 \%$ or more. Values are cumulative number of seeds germinated after second sorting as a percentage of seeds incubated

\begin{tabular}{llllllll}
\hline & \multicolumn{7}{c}{ Heat-Treatment Duration } \\
\cline { 2 - 8 } Progenies & Seed Size & $\mathbf{6 0}$ days & $\mathbf{8 0}$ days & $\mathbf{1 0 0}$ days & $\mathbf{1 2 0}$ days & Means & SE \pm \\
\hline A5240 & 1.70 & 92.43 & 86.89 & 81.61 & 82.84 & $85.94^{\mathrm{a}}$ & 2.44 \\
$\mathbf{A 5 2 9 1}$ & 2.38 & 84.00 & 68.85 & 41.29 & 30.81 & $56.24^{\mathrm{b}}$ & 12.25 \\
$\mathbf{A 5 2 3 4}$ & 1.81 & 85.21 & 75.20 & 10.01 & 30.03 & $50.11^{\mathrm{b}}$ & 17.96 \\
$\mathbf{A 5 2 2 1}$ & 1.81 & 94.81 & 85.21 & 90.00 & 68.12 & $84.54^{\mathrm{a}}$ & 5.81 \\
Means & & $89.11^{\mathrm{a}}$ & $79.04^{\mathrm{b}}$ & $55.73^{\mathrm{c}}$ & $52.95^{\mathrm{c}}$ & & \\
SE \pm & & 2.66 & 4.26 & 18.58 & 13.35 & & \\
\hline
\end{tabular}

Progeny means (column) and heat-treatment means (row) with the same letters are not significantly different $(P$ $<0.05$ ).

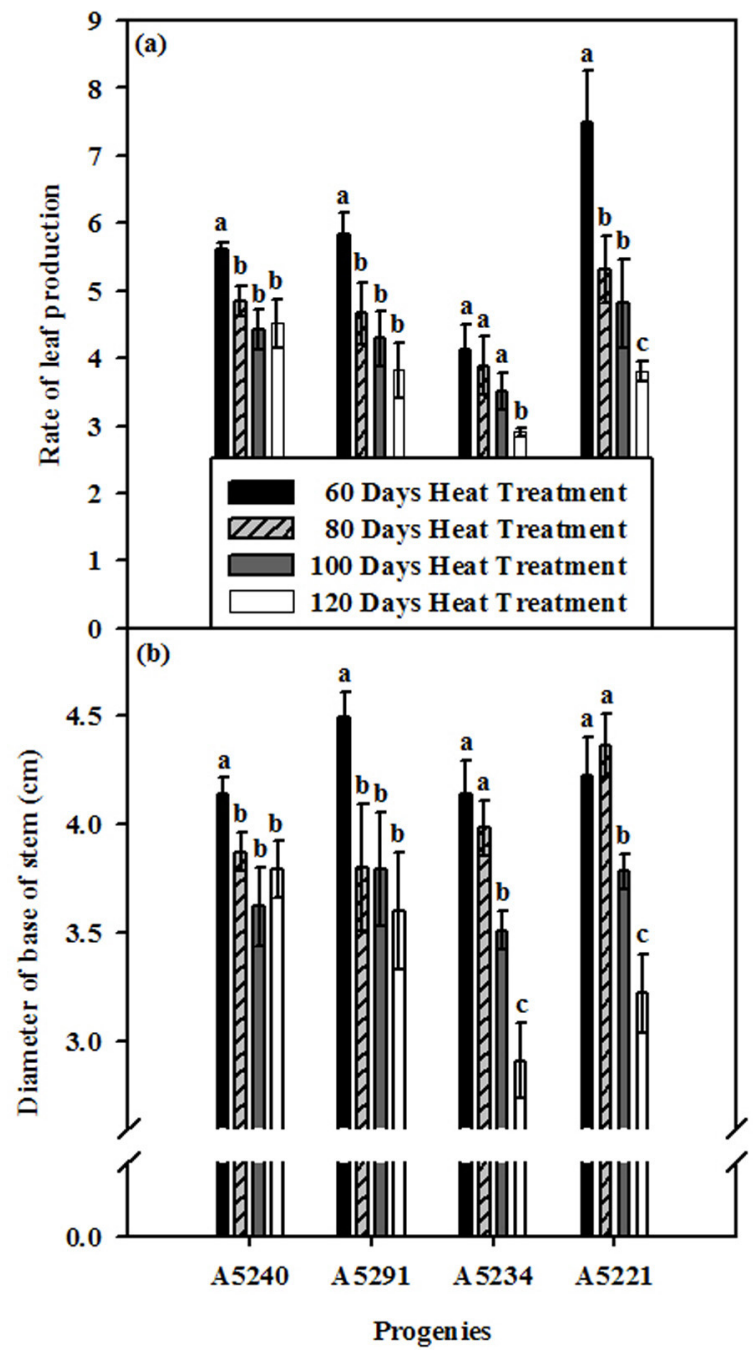

Figure 1. Rate of leaf production (a) and diameter of base of stem (b) of four oil palm progenies exposed to different durations of heat-treatment to break dormancy. The bars are means \pm S.E of 16 oil palm seedling for each progeny in three replicates. Bars with the same letter within a progeny are not significantly different $(P<$ 


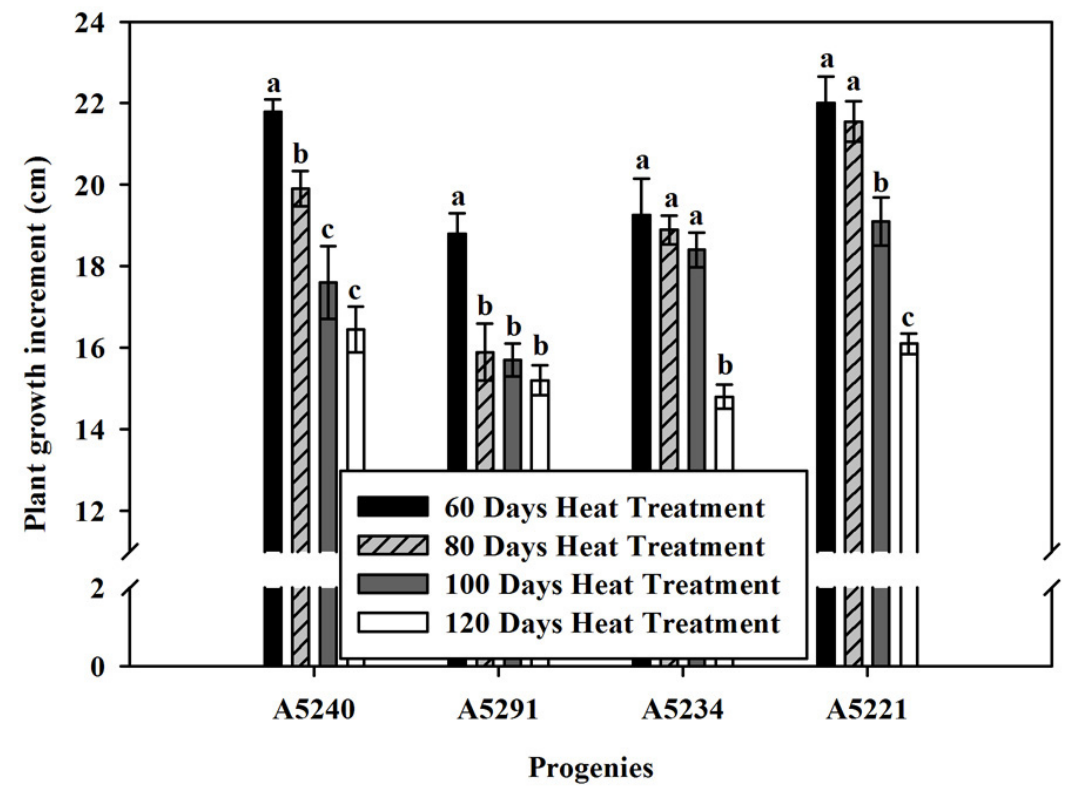

Figure 2. Seedling growth increment of four oil palm progenies exposed to different durations of heat-treatment to break dormancy. The bars are means \pm S.E of 16 oil palm seedling for each progeny in three replicates. Bars with the same letter within a progeny are not significantly different $(\mathrm{P}<0.05)$ 


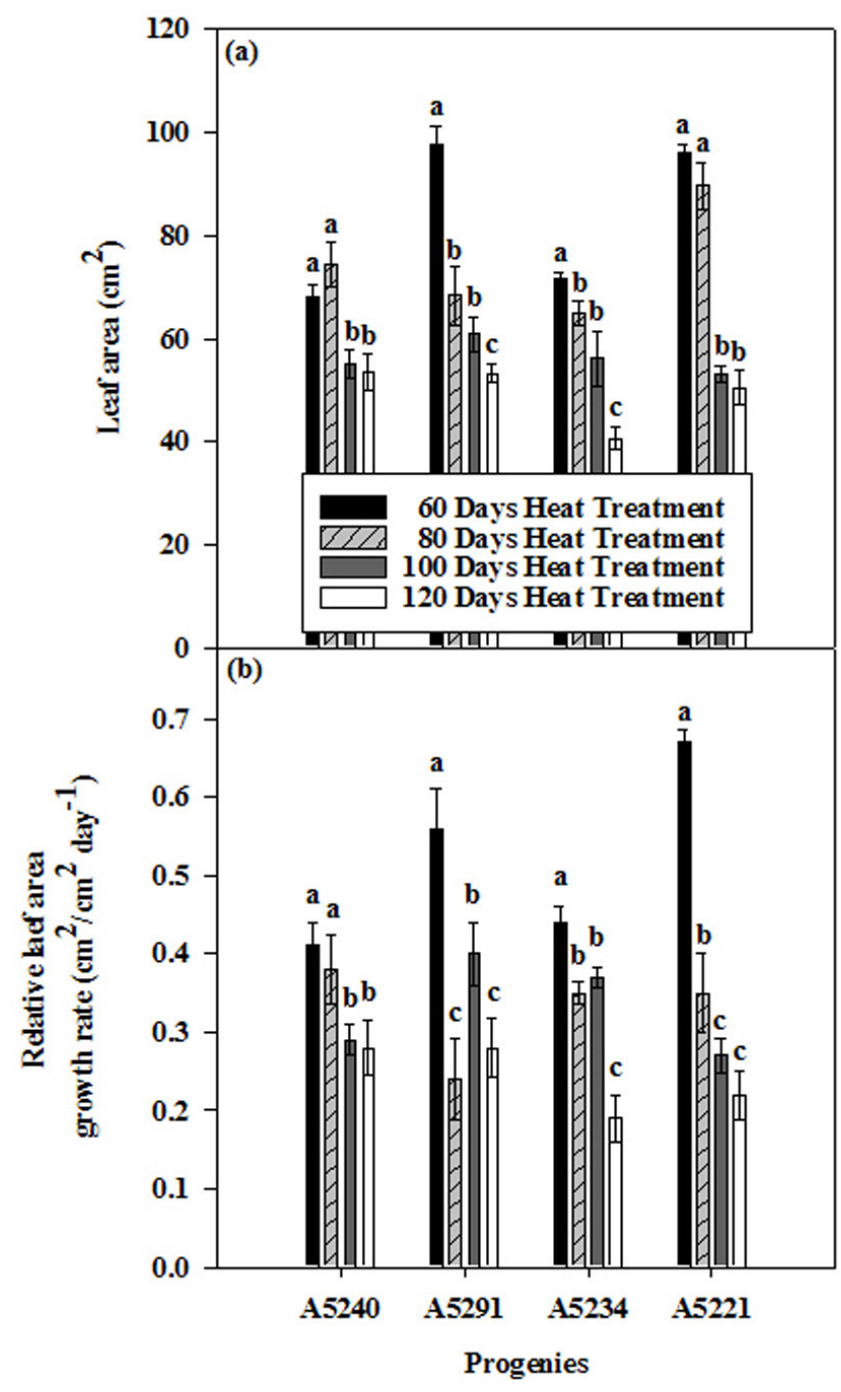

Figure 3. Leaf area (a) and relative leaf are growth rate (b) of four oil palm progenies exposed to different durations of heat-treatment to break dormancy. The bars are means \pm S.E of 16 oil palm seedling for each progeny in three replicates. Bars with the same letter within a progeny are not significantly different $(P>0.05)$ 